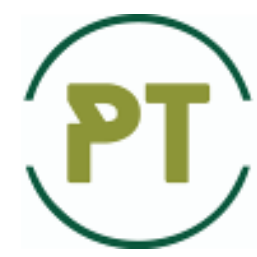

Problems of Tribology, V. 25, No 2/96-2020, 49-58

Problems of Tribology

Website: http://tribology.khnu.km.ua/index.php/ProbTrib

E-mail: tribosenator@gmail.com

DOI: https://doi.org/10.31891/2079-1372-2020-96-2-49-58

\title{
Application of polymer composites in the design of agricultural machines for tillage
}

\author{
V.V. Aulin ${ }^{2}$, O. D. Derkach ${ }^{1}$, O.S. Kabat ${ }^{1}$, D.O. Makarenko ${ }^{1}$, A.V. Hrynkiv ${ }^{2}$, D.I. Krutous ${ }^{1}$ \\ ${ }^{1}$ Dnipro State Agrarian and Economic University, 25 Serhiy Yefremov St., Dnipro, Ukraine \\ e-mail: addsau@gmail.com \\ ${ }^{2}$ Central Ukrainian National Technical University, avenue University, 8, Kropivnitskiy, Ukraine \\ e-mail: aulinvv@gmail.com
}

\begin{abstract}
The article includes an analysis of the state of production of crop production in Ukraine and a description of the shortcomings in the work of cultivators.It was proposed to modernize the construction of cultivators with the help of polymer composite materials. We recommend the introduction of a polymer composite CCPA-6-30 in the construction of cultivators, it has high tribotechnical characteristics.

Key words: carbon plastic, cultivator, tribotechnical characteristic, abrasive.

\section{Introduction}

Ukraine is one of the largest agrarian countries. The area of arable land in Ukraine is about 32,5 million hectares. The largest latifundists, which occupied about $15 \%$ of arable land, were such agroholdings as Ukrlandfarming (630000 hectares), NCH (430000 hectares), KernelGroup (700000 hectares) and others [1]. Small farms occupied 12, and about $73 \%$ - other agro-enterprises of different sizes and forms of ownership. At the same time about half of the crop of early grain and leguminous crops for export. These crops were grown for intensive, industrial technologies using modern methods of seed preparation, chemical protection and plant care, and others.
\end{abstract}

Table 1

Grouping of agricultural enterprises by size of sown area in Ukraine [2]

\begin{tabular}{|l|c|c|c|c|}
\hline \multicolumn{1}{|c|}{ Area, hectare } & $\begin{array}{c}\text { Number of } \\
\text { enterprises, units }\end{array}$ & In\% to the total & $\begin{array}{c}\text { Sown area, } \\
\text { thousand hectares }\end{array}$ & In\% of total area \\
\hline All of them: & 45613 & 100 & 19811,2 & 100 \\
$20,0 \ldots 50,0$ & 24596 & 53,9 & 548,3 & 2,8 \\
$50,1 \ldots 100,0$ & 4606 & 10,1 & 338,2 & 1,7 \\
$100,1 \ldots 250,0$ & 4713 & 10,3 & 774,1 & 3,9 \\
$250,1 \ldots 500,0$ & 3232 & 7,1 & 1171,5 & 5,9 \\
$500,1 \ldots 1000,0$ & 2925 & 6,4 & 2103,6 & 10,6 \\
$1000,1 \ldots 2000,0$ & 2822 & 6,2 & 4045,7 & 20,4 \\
$2000,1 \ldots 3000,0$ & 1277 & 2,8 & 3096,9 & 15,6 \\
More then 3000,0 & 1442 & 3,2 & 7732,9 & 39,1 \\
\hline
\end{tabular}


It is concluded that the main agricultural enterprises in Ukraine are farms with an area of more than 3000 hectares. It occupy $39.1 \%$ of the total acreage, their number at the same time is only $3.2 \%$ of the total number of farms. Most of these enterprises are used in the cultivator processing system for presowing continuous tillage.

Also, there are many manufacturers of tillage machines in Ukraine. The most famous are: Veles-Agro, Elvorti, Belotserkovmaz, Lozova Machinery, Agrokalina and others. However, the reliability of tillage equipment from these manufacturers is lower, than that of foreign equipment.

We have investigated, that it is possible to increase reliability agricultural machine for tillage by using new materials - polymeric composites - that have high tribological properties and do not require maintenance (lubrication).

The human used natural polymers for many years: cellulose, rubber, leather. Synthetic polymers were first obtained in the first half of the twentieth century, this is the beginning of the century of synthetic polymer materials.

Now a special place in the modernization of machines belongs to plastics, increasing their reliability, reducing metal consumption. The unique properties of plastics improve designs, improve their quality, reduce cost, increase labor productivity [3, 4].

Plastics used in engineering are divided into five groups: decorative, structural, antifriction, anticorrosive, electrical insulating.

To improve the technical level of machines and agricultural machinery use structural and antifriction plastics. For this purpose: polyamides, polyethylene with various dispersed and fibrous fillers are often used [58].

Today, the use of complex plastics with different modifiers and fillers form a new group of high-tech materials - polymer composite materials. Application of polymeric composite materials in engineering and agriculture occupies an important place. This also applies to soil-cultivating machinery, which is improved for agronomic requirements $[4,9]$.

\section{Literature Review}

The problem of the development and introduction of new structural plastics in agricultural machinery was investigated by many scientists, such as Abramov L.M., Kreidlin L.M., Klimchuk Y.F., Burya O.I., Tsurpal I.A., Murgas M. [10-14] and others. The aging processes of plastics [15] and heat treatment methods [16] were studied to optimize the physico-mechanical and chemical properties of articles. The results obtained in the research and introduction of polymeric composite materials in agricultural crops. engineering showed that the use of carbon plastics gives good results, because they simultaneously combine a wide range of properties [17$19]$, this is not present in other materials and composites. When using them in agricultural machines, the resource, reliability, and energy intensity are increased. A carbon fiber based on polyamide- $6(6,6,12$ and others) and phenolone [20-22] are used. The problems of introducing polymeric composite materials into the design of modern complex seeding complexes have been solved and realized [3, 23].

Cultivators may be equipped with a parallelogram mechanism to ensure the most qualitative preparation of the soil, the main task of the mechanism is to copy the soil surface and ensure a stable seedbed.

Parallelogram mechanism of cultivators (Fig.1) is a multi-hinged system for fastening the four-link mechanism, the links constitute a parallelogram. Such a system ensures high-quality copying of the field relief and a constant angle of the working element with respect to the field.

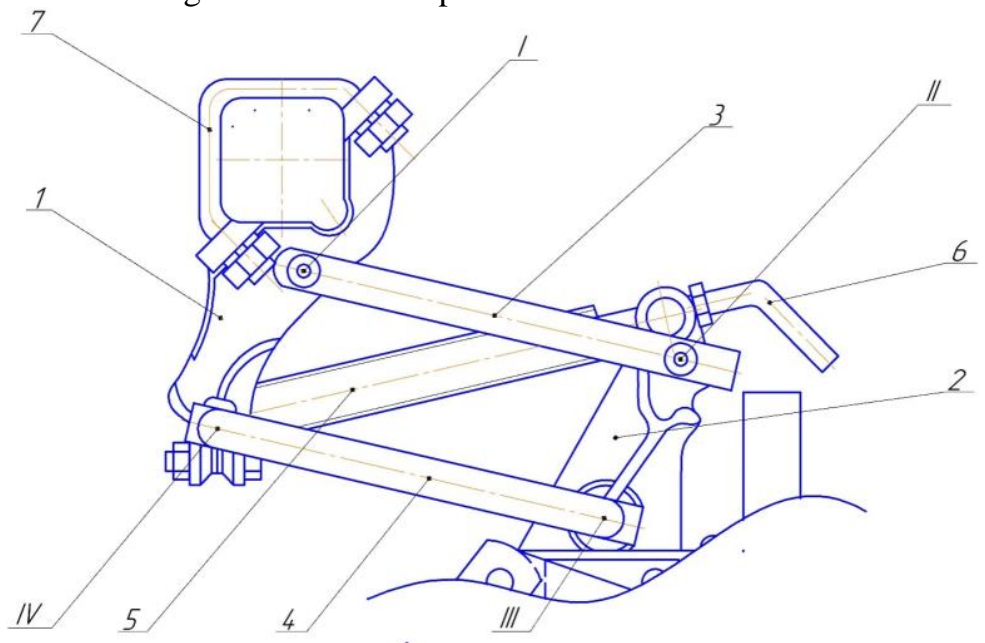

Fig. 1 - Parallelogram mechanism: 1 - the front bracket, 2 - the rear bracket, 3 - the upper link of the mechanism, 4 - the lower link of the mechanism, 5 - the spring, 6 - the adjusting screw, 7 - the bracket clamp, I, II, III, IV, - places of wear. 
During the operation of the parallelogram mechanism of cultivators KРH-5,6, КПС-8 "Voskhod", KP-6 Maxym-6, and others, faults were detected, such as intensive and premature wear of the axis of the links of the mechanism. This leads to a violation of the technological process of cultivation and non-compliance with agrotechnical requirements. The manufacturing plants introduced system lubrication of hinges with plastic materials. The frequency is $48 \ldots 100$ hours. But, for large width of cultivator capture, the maintenance of mechanisms leads to significant overstrain of the aggregates, which leads to a violation of the agrotechnical terms of cultivation.

Positions I, II, III, IV are the axes that are most worn out during the movement of the links of the parallelogram mechanism. We suggest placing them in bushings made of polymer composite materials that will have good physicomechanical and tribological properties.

Scientists Kozachenko O.V., Shkregal O. M., Svirin O.M., Babitsky L.F., Kuvshinov A.A., Tarasenko V.I., Mancinskiy Y.O. were engaged in the improvement of cultivator designs and their working organs. They investigated the stability of rectilinear motion, the oscillatory device of the cultivator paws, and improved the design of the working organs. However, these works were not aimed at the introduction of polymer composite materials in their design.

Based on the conducted studies, we can conclude that a promising direction in improving the design of the parallelogram mechanism is the introduction into the design of parts made of polymer composite materials (PCM).

In [4, p. 45] describes the use of polymeric composite materials based on aliphatic polyamide CCPA-6-40 in this mechanism, but its increased hygroscopicity led to wedging of the hinges of the mechanism after seasonal storage. Also, sometimes materials that have a complex, low-productivity and energy-intensive processing technology [25] have been proposed for use in similar mechanisms.

Previously, we found that polymer composite materials based on aliphatic polyamides provide a stable process of friction and wear in similar mechanisms [3,27-29]. We calculated that the allowable load in parallelogram mechanisms of sowing machines, equipped with PCM is $2377 \mathrm{~N}$.

The introduction of polymer-composite materials in the construction of agricultural machines requires careful experimental studies of the characteristics and properties of polymer-composite materials, structural designation, especially tribotechnical, resource, operational, etc.

\section{Materials and Methods}

Method of research of relative abrasive stability of materials

The manufactured samples for the research of relative abrasive stability were linear dimensions $53 \times 29 \times$ $7 \mathrm{~mm}$, which comply with GOST 23.208-79 (Fig. 2).

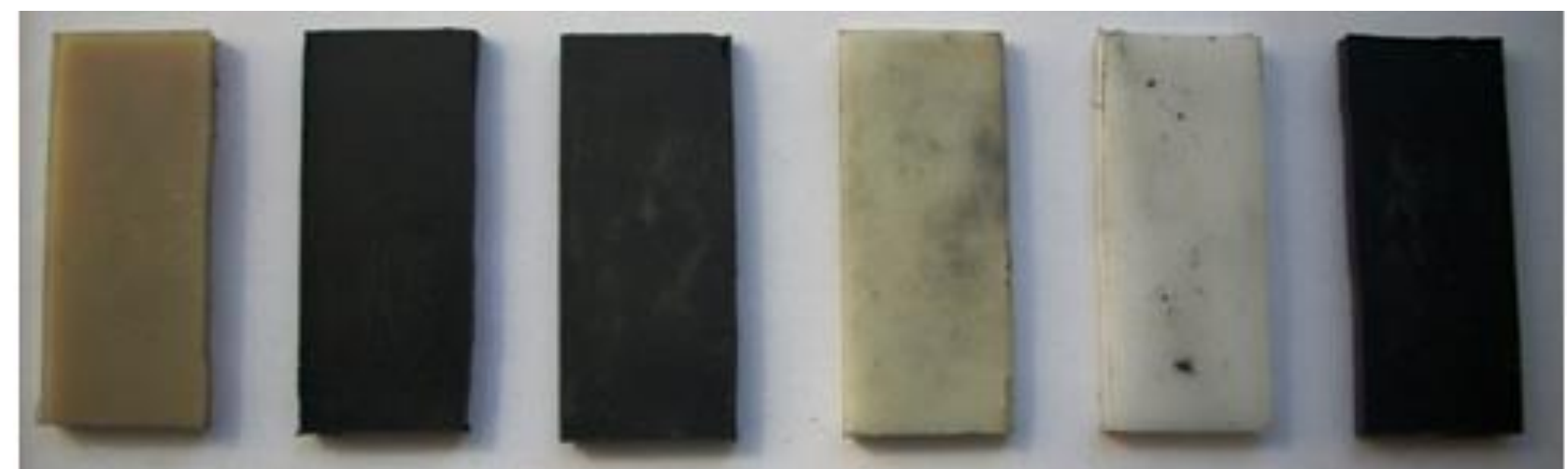

1

2

3

4

5

6

Fig. 2. General view of samples for determining relative abrasive stability: 1 - Nylon 66; 2 - PA-6-210X; 3 - PA6/6.6 R196-GF30; 4 - Kocetal GF705; 5 - Kocetal K300; 6 - CCPA-6-30

The research of samples on the relative abrasive resistance was carried out on a specially laboratory equipment installed (Fig. 3) on the basis of the friction machine СМЦ-2.

The essence of the method was that under the same conditions, forced wear of the studied and reference samples was carried out. Wear was carried out using an abrasive non-rigidly fixed material (electric iron No. 16$\mathrm{N}$, GOST 3643-71), which was fed to the friction zone and pressed to the specimen with a rotating rubber roll (Fig. 3, b). 


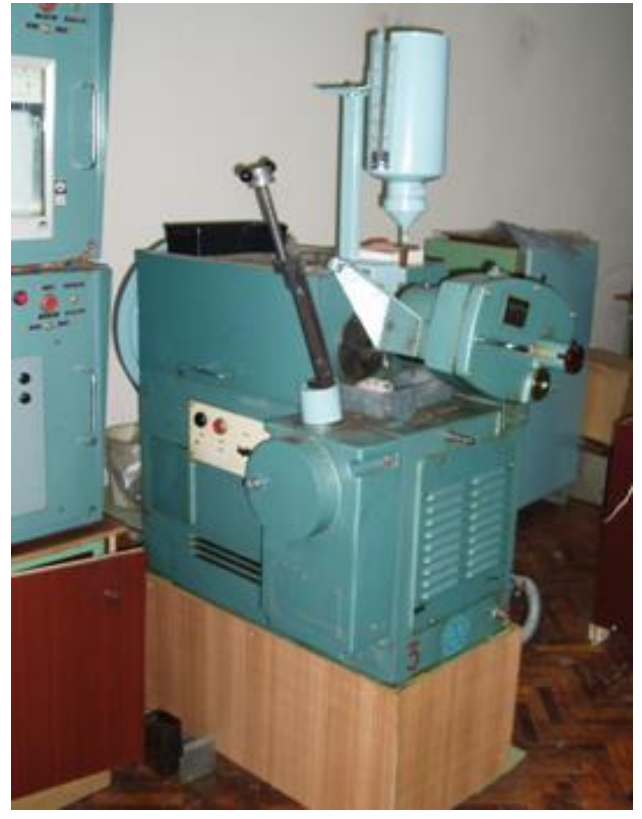

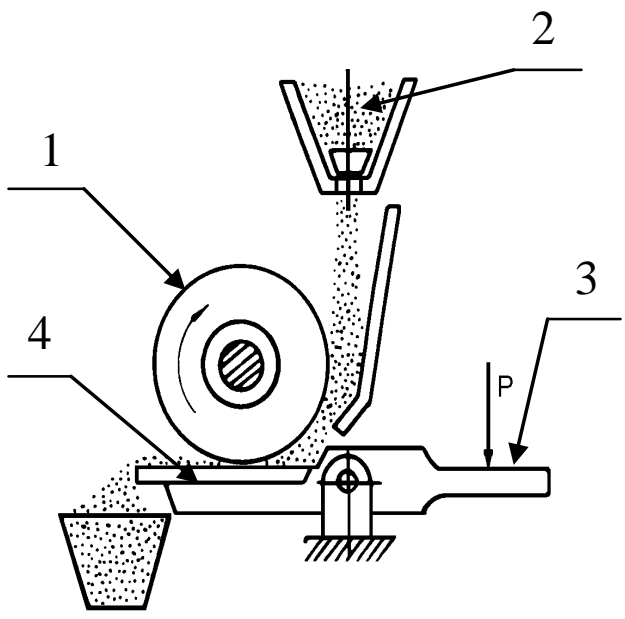

b

Fig. 3. Friction machine СМЦ-2 (a) and scheme of implementation of the process of abrasive wear (b): 1 rubber roller; 2 - abrasive material; 3 - mechanism of load creation; 4 - a sample of the studied material.

Before the test, the abrasive was dried to a relative humidity of no more than $0.16 \%$. The spinning of the roller was carried out by friction method on the surface of a grinding paper type 2 (GOST 6456-75) with grainy number 8P (GOST 3647-71), fixed in a sample holder on a flat steel plate. After spin, the roll was washed in gasoline. Test conditions are given in Table. 2.

The following equipment was also used for research purposes: drying chamber СНОЛ- 465/4; analytical balance of ВЛР-200 with an accuracy of $0.2 \mathrm{mg}(0.0002 \mathrm{~g})$; calipers ШЦ-125, precision class 2, serial number E99344; other auxiliary non-standard equipment.

Test conditions when wearing is not hard fixed abrasive particles

Table 2

\begin{tabular}{|c|c|c|c|c|c|}
\hline \multirow{2}{*}{ Load, $\mathrm{N}$} & \multirow{2}{*}{$\begin{array}{c}\text { Frequency of } \\
\text { rotation, }\end{array}$} & \multicolumn{3}{|c|}{ Specification of rubber roller } \\
\cline { 3 - 5 } & $\begin{array}{c}\text { revolutions per } \\
\text { minute }\end{array}$ & Diameter, mm & Width, mm & $\begin{array}{c}\text { Hardness } \\
\text { according to } \\
\text { GOST 263-75 }\end{array}$ & $\begin{array}{c}\text { Relative ultimate } \\
\text { elongation, \% }\end{array}$ \\
\hline 44 & 60 & $50 \mathrm{MM}$ & $15 \pm 0,1$ & $78-85$ & $15-20$ \\
\hline
\end{tabular}

The weight of the samples was determined by weighing before and after the test. Relative durability of the investigated material was calculated by the formula:

$$
K_{u}=\frac{U_{e} \cdot \rho_{\partial} \cdot n_{\partial}}{U_{\partial} \cdot \rho_{e} \cdot n_{e}},
$$

where $\rho_{\mathrm{e}}, \rho_{\mathrm{z}}-$ density of reference and investigated materials, $\mathrm{kg} / \mathrm{m}$;

$\mathrm{n}_{\mathrm{e}}, \mathrm{n}_{\mathrm{z}}$ - number of roller rotations during tests of reference and test samples;

$\mathrm{U}_{\mathrm{e}}, \mathrm{U}_{\text {д }}-$ wear of reference and investigated samples, $\mathrm{kg}$.

The density of samples $\rho$ was determined by the method of hydrostatic weighing according to GOST 15139-69. The arithmetic mean value of density, obtained as a result of at least three measurements, differing no more than $1 \%$, was taken for the final result. In order to compare the relative abrasive stability of the PCM, which are studied simultaneously, a control material (Nylon 66), the absolute value of which wear was taken per unit, was selected.

Methods of determination of tribotechnical characteristics and properties of elements of movable connections 
The study of the properties of moving compounds materials was carried out on the basis of original and standard techniques.

Tribotechnical characteristics of parts of mobile joints with PCM when not rubbed greased were determined on a friction and wear machine СМЦ-2.

Indicators of the potentiometer КСП-2 were fixed on a special chart paper GOST 7826-75. The tests were performed according to the "disk-block" scheme. The radius of the sample was $\mathrm{R}=0.0025 \mathrm{~m}$.

Before the beginning of each test, the samples were cleaned. This was done so that the friction surfaces of the samples had a parallel shape and the contact area was at least $85 \%$.

Friction coefficient of slip was determined by the formula:

$$
f=\frac{M_{\kappa p}}{P \cdot \Delta},
$$

where $\mathrm{M}_{\mathrm{kp}}$ is the the torque that occurs on the disk, $\mathrm{N} \cdot \mathrm{m}$;

$\mathrm{P}$ is the load on the sample, $\mathrm{N}$;

$\Delta$ is the step of the paper, $\mathrm{m}$. For all experiments the same, $\Delta=0.0025 \mathrm{~m}$.

The temperature in the friction zone was measured using the chromed-alumel electronic thermocouple "Termometer 301 Type K". The hole for measuring the temperature is carried out at a depth equal to half the diameter of the sample, and at a distance of $1.0 \mathrm{~mm}$ from the surface of the friction.

The contact area of the tribo-conection "disc-finger" was $2.0 \mathrm{~cm}^{2}$. Test mode: $\mathrm{p}=0.5 \mathrm{MPa}, \mathrm{v}=0.785 \mathrm{~m} / \mathrm{s}$. The process of rubbing occurred in the following modes: maximum specific pressure $\mathrm{p}=0.25 \mathrm{MPa}$, slip velocity $\mathrm{v}=0.785 \mathrm{~m} / \mathrm{s}$. It the curing process was completed when reaching the contact area of the pad with a conjugate sample of $85 \%$ of the projection area.

The number of repetitions of all experiments is 3 .

\section{Thermal treatment method for protection against environmental impact}

In order to solve the problem of protection of PCM from the negative influence of the external environment, it is proposed to heat the finished parts processing with PCM in the following lubricants: MC-20, ПМС-400, and И-40.

Thermal treatment of composite materials in drying chamber:

- $\quad$ temperature $-120{ }^{\circ} \mathrm{C}$;

- $\quad$ heating and cooling mode $-1{ }^{\circ} \mathrm{C} / \mathrm{min}$.;

- $\quad$ exposure time - $120 \mathrm{~min}$.

\section{Results and Discussion}

Six types of polymer-composite materials were used to study: Nylon 66, PA-6-210X, PA6 / 6.6 R196GF30, KocetalGF705, KocetalK300 and CCPA-6-30. The research carried out on the relative abrasive stability of polymer composite materials, which showed (Fig.4), that sample № 1 (Nylon 66) has the highest relative abrasive resistance and substantially differs positively from other materials. The visual ranking of samples according to the criterion of relative abrasive stability showed, that the Kocetal GF705 material ( 5 times lower than standard) has the lowest abrasive durability.

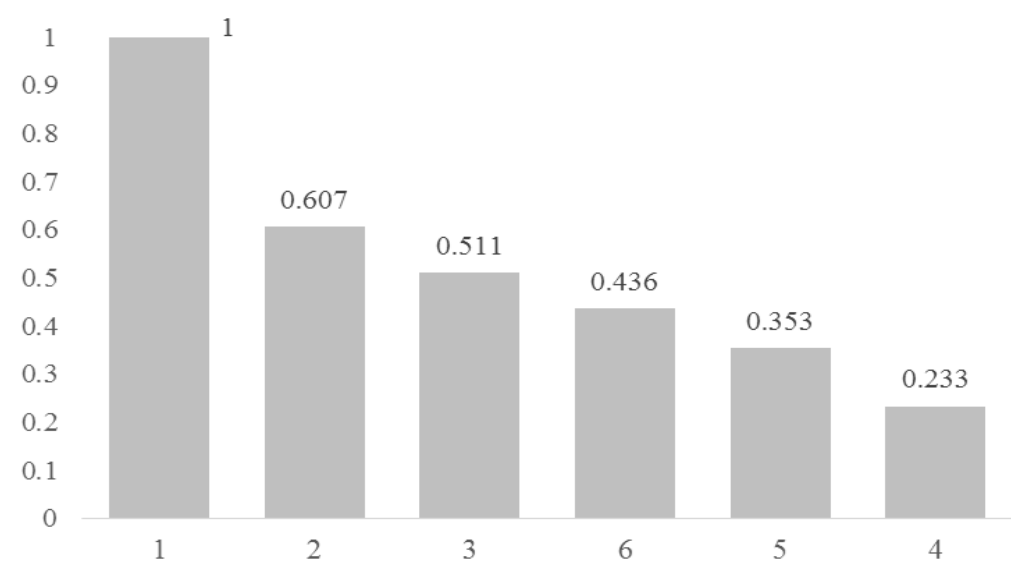

Fig. 4. Ranking of experimental samples according to the criterion of relative abrasive stability 
Found, that under identical test conditions, with a factor of $\mathrm{pv}=0,392 \mathrm{MPa} \cdot \mathrm{m} / \mathrm{s}$, the minimum wear was made from samples made from CCPA-6-30, the maximum wear - samples made of Kocetal material GF705(Fig. 5). In addition, other polymer-composite materials have a value of wear, an order of magnitude larger than CCPA-6-30.

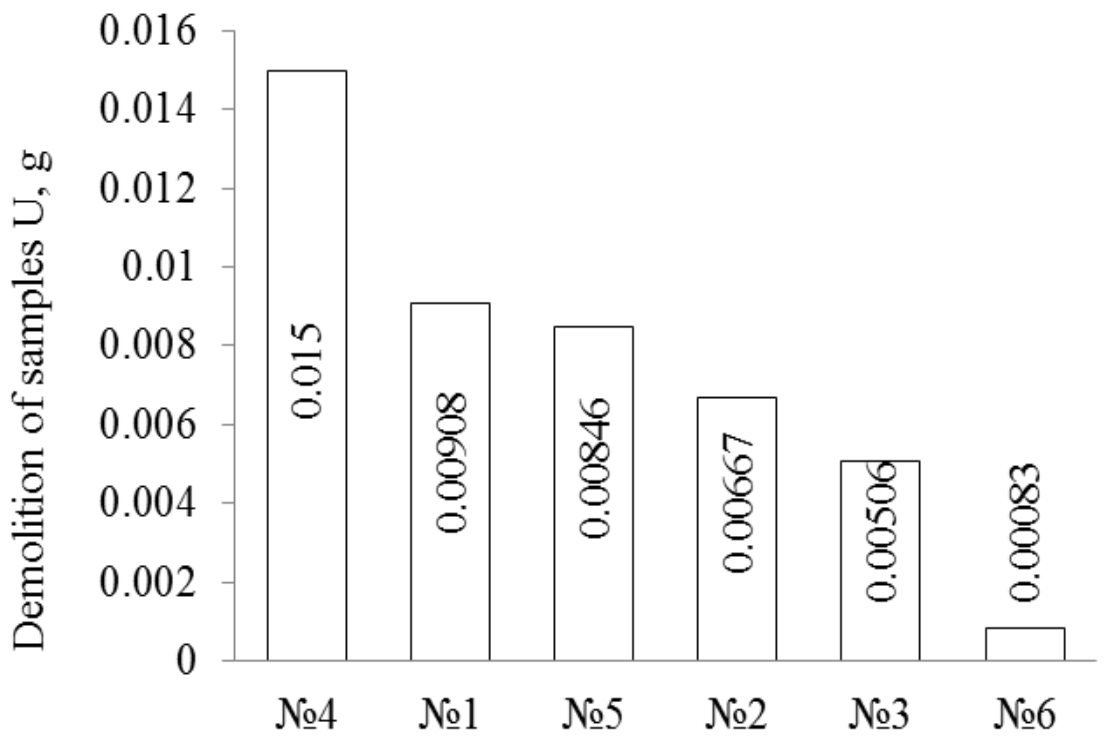

Fig. 5. The value of weight deterioration of polymer specimens with friction without lubricating on steel 45 (experimental conditions $\mathrm{p}=0.5 \mathrm{MPa}, \mathrm{v}=\mathbf{0 . 7 8 5} \mathrm{m} / \mathrm{s}$ )

Determination of friction coefficient $f$ showed, that its value is within the limits of $0,16 \ldots 0,49$ (Fig. 6). The results of the temperature research in the friction zone (Fig. 7) indicate that this parameter correlates with the values of friction coefficient $\mathrm{f}$.

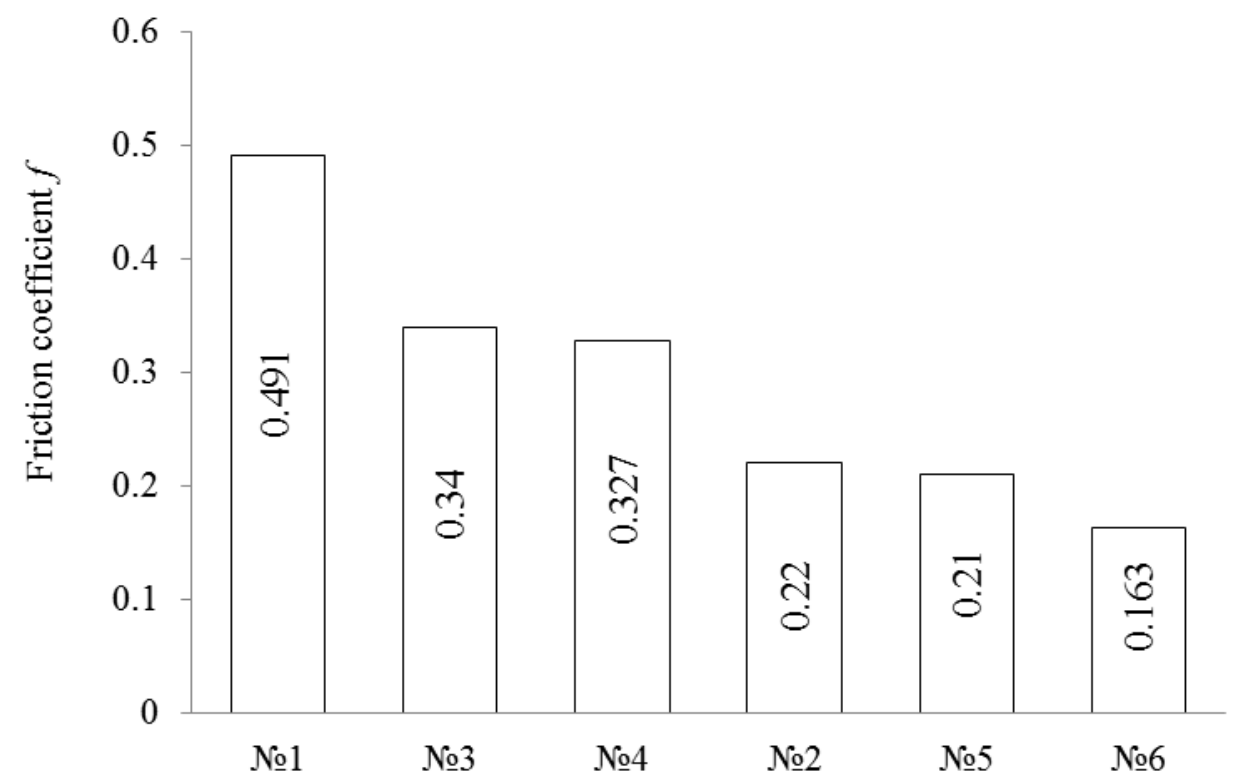

Fig. 6. Friction coefficient in the frictional interaction of a steel conjugate sample with polymer specimens: № 1 - Nylon 66; № 2 - PA-6-210X; № 3 - PA6/6.6 R196-GF30; № 4 - KocetalGF705; № 5 - KocetalK300; № 6 - CCPA-6-30 


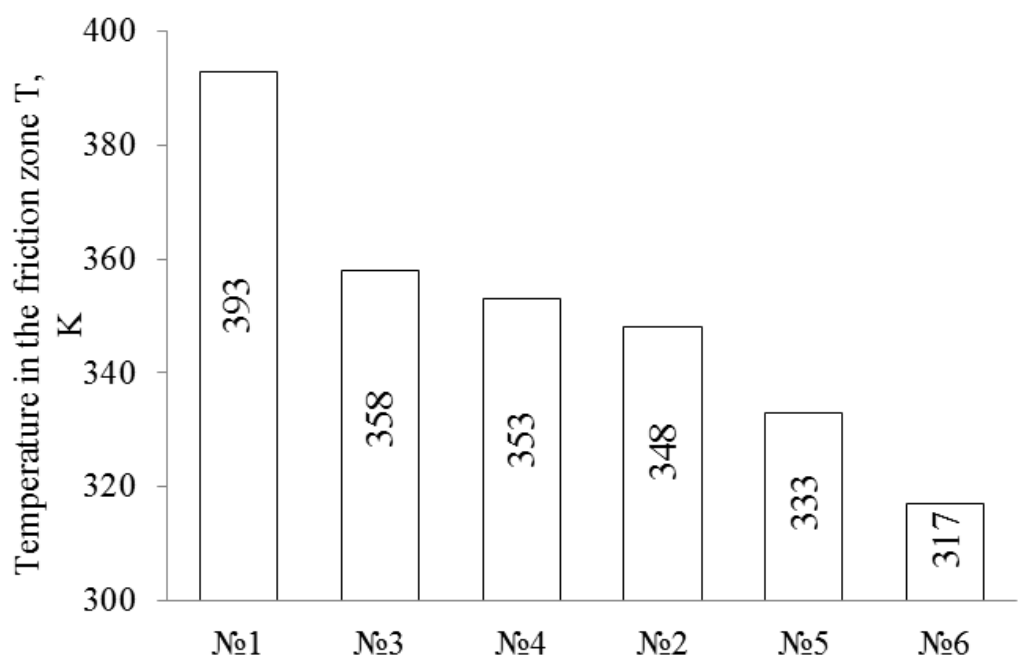

Fig. 7. Temperature in the friction zone in the frictional interaction of the steel conjugate part with polymer samples:

№ 1 - Nylon 66; № 2 - PA-6-210X; № 3 - PA6/6.6 R196-GF30;

№ 4 - KocetalGF705; № 5 - KocetalK300; № 6 - CCPA-6-30

Stabilization of temperature $\mathrm{T}$ in the friction zone for all samples comes in the range of 8 minutes. (for Kocetal GF705) up to 40 minutes (Nylon 66) (Fig. 8).

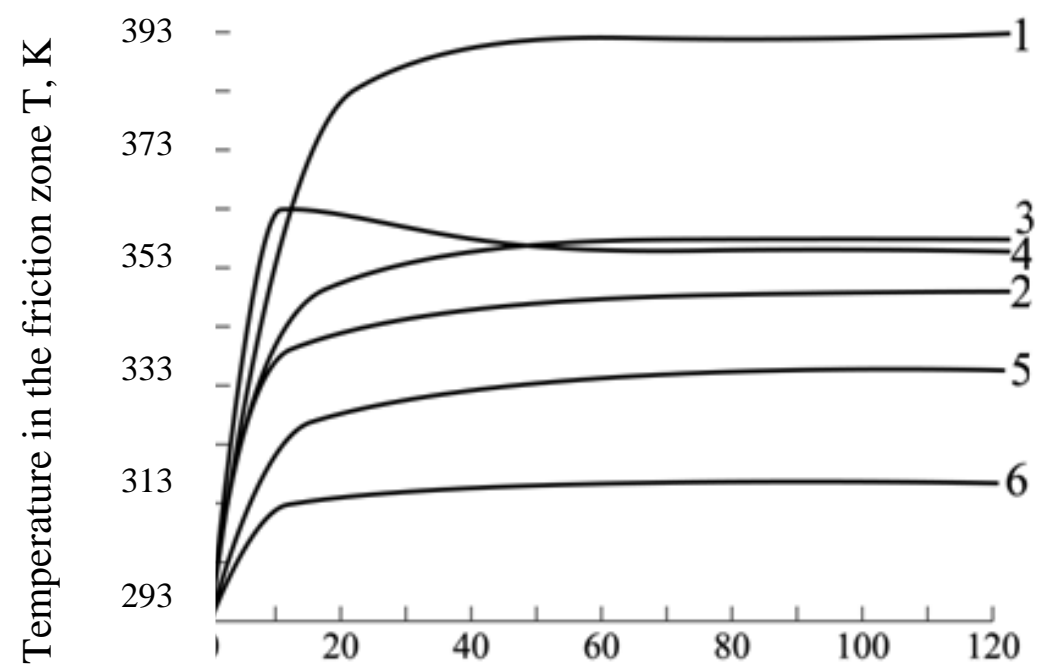

Duration of experiment, min

Fig. 8. Dependence of temperature on the friction surface in the frictional interaction of the steel conjugate sample with the polymer samples from the time of the experiment:

№ 1 - Nylon 66; № 2 - PA-6-210X; № 3 - PA6/6.6 R196-GF30;

№ 4 - KocetalGF705; № 5 - KocetalK300; № 6 - CCPA-6-30

The general view of the experimental parts made of polymeric-composite material CCPA-6-30 is shown in Fig. 9

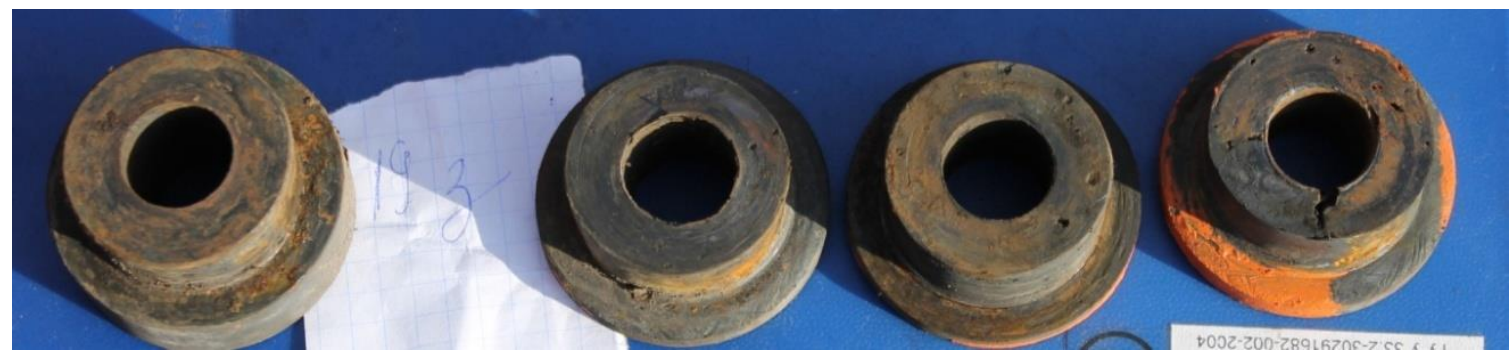

Fig. 9 - General view of experimental details of the upper lever after testing in paralelogram mechanism of cultivator 
We have developed methods for heat treatment in oils [23, 30-32], which make it impossible to hygroscopic PKM based on aliphatic polyamides in volumes that led to a change in geometric dimensions or changes in properties.

Table 3

Influence of heat treatment in oil on the strength of polymeric composite materials of grade CCPA-6-30

\begin{tabular}{|l|c|c|c|}
\hline \multicolumn{1}{|c|}{ Parameter } & Control & After processing & Deviation, $\%$ \\
\hline Strength of compression strength $\sigma, \mathrm{MPa}$ & 134,7 & 133,1 & 1,18 \\
\hline Modulus of elasticity E, MPa & 1883,1 & 1743,9 & 7,39 \\
\hline
\end{tabular}

The results of the research have shown, that the Nylon 66 PCM, which provides relative abrasive stability, is 39\% higher than the PA-6-210X composite and 77\% higher than Kocetal GF705.

It is not recommended to use as abrasive resistant materials Kocetal GF705 and Kocetal K300.

On the basis of the obtained data it can be assumed that the materials of the specimens for №№2, 5, 6 are antifriction because they have a coefficient of friction $\mathrm{f}<0.3$, and the materials of the specimens for №№1, 3, 4 are frictional materials with moderate high coefficient of friction, therefore their use in movable connection of cultivators is inappropriate.

The research of the dependence of friction coefficient $f$ on the duration of the experiment showed that the stabilization $\mathrm{f}$ for all samples comes after $3 \ldots 22 \mathrm{~min}$. from the beginning of the test. For samples №2 - 6, during 120 minutes, f did not increase, or its deviations were within the measurement error. Only when tested with a Nylon 66 PCM sample this indicator slightly increased steadily. The growth rate of this parameter was 0.01 (h) 1 .

In order to ensure the stable operation of mobile machines and mechanisms operating under conditions of friction without lubrication and a small amount of abrasive, it is recommended to use a polymer composite UPA-6-30, which at a specific pressure $\mathrm{p}=0.5 \mathrm{MPa}$ and slip velocity $\mathrm{v}=0,785 \mathrm{~m} / \mathrm{s}$ provides a minimum friction coefficient $(f=0,16)$, temperature in the friction zone $(T=313 \mathrm{~K})$; their own wear, which is an order of magnitude smaller than the other samples being studied. This composite has stable performance over long periods of operation.

In general, the proposed method of heat treatment [23] reduced the hygroscopicity of this polymer composite material, and the amount of moisture accumulated during the storage of equipment decreased from $0.70 \%$ to 0.35 .

This technology is realized in Development Enterprise "Soyuz-Composite"[19] and recognized as costeffective.

\section{Conclusion}

The use of polymer composite materiales in hinged joints of parallelogram mechanisms of soil tillage machines will improve the quality of the implementation of agrotechnical requirements, eliminate the cost of idle time during the maintenance of mechanisms, reduce the cost of operation and maintenance of modernized cultivators. It is recommended for applications in parallelogram mechanisms in which the maximum load on the hinge is $2400 \mathrm{~N}$.

\section{References}

1. Derkach O.D. Vikoristannya shirokozahvatnoYi tehnIki v umovah prirodnogo zemlerobstva / O.D. Derkach, D.O. Makarenko // Prirodne agrovirobnitstvo v UkraYinI: problemi stanovlennya, perspektivi rozvitku: MIzhnar. nauk.-prakt. konf. - DnIpropetrovsk: DDAEU, 2015. - S. 52-54. (Ukr)

2. Statistichniy schorIchnik UkraYini za 2014 rIk. Derzhavniy komItet statistiki UkraYini. - K.: $/ \ll$ Konsultant»/, 2015. - 534 s. (Ukr)

3. Derkach A., Makarenko D., Naumenko N. Primenenie ugleplastikov v shirokozahvatnyh posevnykh mashinakh. Mechanization in agriculture / International scientific, scientific applied and informational journal. YearLXI, 2/2015, Sofia, c. 3-6. (Rus)

4. Burya A. Modernizatsiya pantographnogo mekhanizmu kultivatora KP-6 "Maksym". The international scientific and practical conference "Complex zabezpechennya jakcosti tehnologichnykh protsessiv ta sistem". 2015. - P. 45-46. (Ukr) 
5. Kuznetsova O.Yu. Rozrobka fulerenvmIsnih kompozitnih materIalIv na osnovI fenIlonu dlya detaley konstruktsIynogo priznachennya: Avtoref. dis. kand. tehn. nauk: 05.02.01 / Lutskiy natsIonalniy tehnIchniy unIversitet, 2013. $-23 \mathrm{~s}$. (Ukr)

6. Gatskov V. S. Progressivnyie tehnologii izgotovleniya detaley iz antifriktsionnyih materialov: Uchebnoe posobie. - M.: NIYaU MIFI, 2011. - 152 s. (Rus)

7. Kashitskiy V. P. NaukovI pIdhodi do stvorennya samozmaschuvalnih epoksikompo-zitnih tribomaterIalIv / V. P. Kashitskiy, P. P. Savchuk // NaukovI notatki. - 2015. - Vip. 50. - S. 76-80. (Ukr)

8. Burya A.I., Kuznetsova O. Yu.,Derkach A.D.,Sergiyenko V.P.,Bukharov S.N. Investigation of fullerence $\mathrm{C}_{60}$ influence on tribotechnical and clynamical mechanical properties of composite material based on phenilon. WTC 2013, $5^{\text {th }}$ world tribology congress, September, 8-13, 2013, Torino, Italy.

9. Derkach O.D., Burya O.I. PIdvischennya tehnIchnogo rIvnya elektro-, avtomobIlnogo tran-sportu ta sIlskogospodarskoYi tehnIki za rahunok vikoristannya novih materIalIv. NaukovI rekomendatsIYi: DnIpropetrovsk: DDAU. - 2011. - 71 s.(Ukr)

10. AbramovL., KreidlinL., KlimchukYu. (1980). Sostoyaniye i perspective primeneniya I izgotovleniya plastmassovykh detaley tractorov I selkhoxmashin. Primenenie polimernikh materialov v selkhoxmashinakh, Rostov-na-Donu, 1980, p. 4-7. (Rus) [11] Abramov L. Polimernie materialy v selskhohoziaystvennom mashinostroenii. Monograph - M .: Agropromizdat, 1986. - 225 p.

12. Tsurpal I.A. Perspectivi snizhenia metalloyemkosti I povishinia nadezhnosti selskhohozyaistvennoy tekhniki. Compozitsionnye materialy. - Moskva.: MTSNTI - 1987. - P. 18-32. (Rus)

13. MurgasM. Wear resistant materials for agricultural machinery // Mech. Zemed. - 1990. Vol. 40, №10. - P. 451-453.

14. Burya A.I., Burya A.A., Cherepov S.A.,Rybak T.I. Tribological characteristics of carbon plastics on the basis of polyamide // Journal of the Balkan Tribological Association, 1996, Vol.2, No 3, C.153-160.

15. Pavlov N. Starenie plastmass v yestestvennyh I iskhustvennykh usloviakh. Monograph. - Moskva: Khimia, 1982. - 220 p. (Rus)

16. Kestelman N. Termicheskaia obrabotka polimernykh materialov v mashinostroenii. Moskva: Mashinostroenie, 1968, 266 p. (Rus)

17. Carbon fibre hoops hesten repair of fertilizer tower// Atv. Compos. Bull.-2002. Apr.- P. 4-5.

18. Burya A. Primenenie ugleplastikov - perpectivny put povyshenia nadezhnosti selskhohozyaistvennoytekhniki. Polimernie compozitsionnye materialy. Tezisy dokladov. - Moskva, 1991. - p. 44-45. 28 p. (Rus)

19. BuryaA. Svoystva i opyt primenenia ugleplastikov v selkhoxmashinostroenii. Kiev: Znanie, 1992. -

20. BuryaA. Trenie i iznashivanie ugleplastikov na osnove aromaticheskikh poliamidov. Journal of Friction and Wear. 1989. - T.22, №6. - p.677-683. (Rus)

21. BuryaA., Molchanov B. Trenie i iznos polyamida-6 I ugleplastika na ego osnove. Journal of Friction and Wear. - 1992. -T.13, №5, - p. 900. (Rus)

22. BuryaO. Rozrobka, doslidzhennya I vykorystannya polimeriv, armovanykh khimichnymy voloknamy, v konstruktsiyakh silskhogospodarskykh mashyn. Avtorepherat, Ternopil, 1993. - 32 p.

23. Kobets A., Derkach A., Makarenko D., Shapoval A., Kabat O. Decreasing the environment influence on composite materials / НаучниИзвестия. Scientific Technical Union of Mechanical Engineering, Year XXIV, ISSUE 16 (202), June 2016. IV International Scientific and technical Congress "Agricultural Machinery", 2225.06.2016, Varna, Bulgaria, c.13-15.

24. Silskhogospodarski ta melioratyvni mashyny. Vojtyuk D., Dubrovin V., Ishchenko T. Kyiv: Vyshcha osvita, 2004. - 544 p. (Ukr)

25. Derkach O., Artemchuk V., Muranov Ye. Do pytannia tekhnologichnosti otrymannya detaley z polymernykh compozytiv dlya posivnoi tekhniky. . Visnik HNTUSG im. Petra Vasilenka, - 2017. № 181, p. 157-167. (Ukr)

26. V. Aulin, O. Derkach, D. Makarenko, A. Pankov, A. Tykhyi Analysis of tribological efficiency of movable junctions "polymeric-composite materials - steel". Eastern-European Journal of Enterprise Technologies. - 2019. Vol. 4 (12 - 100). - P. 6-15. DOI: 10.15587/1729-4061.2019.176845

27. V. Aulin, S. A. Hrynkiv, Lysenko, A. Dykha, T. Zamota, V. Dzyura Exploring a possibility to control the stressed-strained state of cylinder liners in diesel engines by the tribotechnology of alignment. EasternEuropean Journal of Enterprise Technologies. - 2019. Vol. 3 (12 - 99). - P. 6-16. DOI: 10.15587/17294061.2019.171619

28. Aulin V. V., Kalich V. M., Hrynkiv A. V., Holub D. V. Prohnozuvannia zalyshkovoho resursu ahrehativ ta system transportnykh zasobiv silskohospodarskoho vyrobnytstva za yikh tekhnichnym stanom. Zahalnoderzhavnyi mizhvidomchyi nauk.-tekhn. zb. Konstruiuvannia, vyrobnytstvo ta ekspluatatsiia silskohospodarskykh mashyn, vyp. 45, ch. II. - Kirovohrad: KNTU, 2015. - S.28-36.

29. V. Aulin, A. Hrynkiv, S. Lysenko, O. Lyashuk, D. Velykodnyi, Y. Vovk, D. Holub, A. Chernai Wear resistance increase of samples tribomating in oil composite with geo modifier KGMF-1. Tribology in Industry Vol. 41, No. 2 (2019) 156-165. 
30. Aulin V.V., Lysenko S.V., Kuzyk O.V., Holub D.V. Trybofizychni osnovy pidvyshchennia nadiinosti mobilnoi silskohospodarskoi ta avtotransportnoi tekhniky tekhnolohiiamy trybotekhnichnoho vidnovlennia. Monohrafiia. - Kropyvnytskyi: vydavets Lysenko V.F., 2016. 304s.

31. Aulin V. V., Hrynkiv A. V. Teoretychne obhruntuvannia metodu i systemy diahnostuvannia stanu mobilnoi silskohospodarskoi tekhniky. Visnyk Kharkivskoho nats. tekhn. universytetu silsk. hospodarstva. / Vyp. 163. Problemy nadiinosti mashyn ta zasobiv mekhanizatsii silskohospodarskoho vyrobnytstva. - Kharkiv. - 2015.-S.39-44.

32. Aulin V. V., Hrynkiv A. V. Teoretychne obhruntuvannia metodu i systemy diahnostuvannia stanu mobilnoi silskohospodarskoi tekhniky. Visnyk Kharkivskoho nats. tekhn. universytetu silsk. hospodarstva. / Vyp. 163. Problemy nadiinosti mashyn ta zasobiv mekhanizatsii silskohospodarskoho vyrobnytstva. - Kharkiv. - 2015.-S.39-44.

Аулін В.В., Деркач О.Д., Кабат О.С., Макаренко Д.О., Гриньків А.В., Крутоус Д.І. Застосування полімерних композиторів у конструкції ирунтообробних машин

Стаття включає аналіз стану виробництва продукції рослинництва в Україні та актуальність застосування культиваторів в існуючих технологіях вирощування культур. Запропоновано модернізувати трибоспряження паралелограмних механізмів культиваторів полімерними композитними матеріалами. За результатами досліджень триботехнічних характеристик ряду полімерно-композитних матеріалів, доведено ефективність використання в конструкції культиваторів полімерний композит УПА-6-30, що має високі триботехнічні характеристики.

Ключові слова: культиватор, вуглепластик, триботехнічні характеристики, абразив 